\title{
HasanuddinLawReview
}

Volume 4 Issue 3, December 2018

P-ISSN: 2442-9880, E-ISSN: 2442-9899

Nationally Accredited Journal, Decree No. 32a/E/KPT/2017.

This work is available at: Microsoft Academic Search.

\section{The Marrakesh Treaty and Facilitating Access to Literary Works in the Field of Knowledge for Blind People}

\author{
Kholis Roisah*, Wendy Budiati Rakhmi \\ Faculty of Law, Diponegoro University, Indonesia. \\ * Corresponding author E-mail: r_kholis@yahoo.com
}

\begin{tabular}{l} 
ARTICLE INFO \\
\hline Keywords: \\
Blind People; Copyright; \\
Facilitating Access, Literary \\
Works \\
How to cite: \\
Roisah, K., and Rakhmi, \\
W.B. (2018). The \\
Marrakesh Treaty and \\
Facilitating Access to \\
Literary Works in the Field \\
of Knowledge for Blind \\
People, Hasanuddin Law \\
Review, 4(3): $315-324$ \\
DoI: \\
10.20956/halrev.v4i3.1539
\end{tabular}

\begin{abstract}
Freedom to gain knowledge, information and technology is very important by everyone including blind people which one realized the right of access to literary works through the Marrakesh Treaty 2013. Regulation about facilitating access to copyright of published works for blind people in Indonesia is still considered inadequate to give protection in the implementation of freedom to gain knowledge. This study applied normative juridical approach described descriptiveanalytically. Accessibility to the scientific work of the blind people is a part of human rights which must be respected, protected and fulfilled by the State. The Government has an important role in the realization of the wider access of the disabled by formalizing the governmental regulation in accordance with the mandate of Article 44 paragraph (4) of the Copyright Act 2014 and the Government shall immediately establish The Disabilities National Commission granted the authority and responsibility to fulfill the facilitation of access for blind people and limited reading by guiding Marrakesh Treaty or by looking at other country's regulatory practices.
\end{abstract}

Copyright (C) 2018 HALREV. All rights reserved.

\section{Introduction}

Social function means that copyright does not always use for the personal interest of the holders, but also can be the benefit for public interest. ${ }^{1}$ One of the restrictions on copyright related to the needs of blind people is the act of copyright reproduction for the needs of the blind people. ${ }^{2}$ According to World Health Organization (WHO) in 2017,3 the number of blind people and print disabled in the world is estimated as many as 253

1 Kastowo. (2015). Rekonstruksi Fungsi Sosial Hak Cipta sebagai Hak Milik, Jurnal Yusticia At Pax, 31 (2): 1-15

2 Pooja Shree, (2015). Disability Exeptions in Copyright, Selvam \& Selvam, https://selvams.com/blog/disabilityexceptions-copyright

3 World Health Organization, 2017 Fact Sheet N 282, Available online at: http://www.who.int/en/newsroom/fact-sheets/detail/blindness-and-visual-impairment, Accessed on Feb 14, 2018. 
million persons, 36 million are blind and 27 million have moderate to severe vision impairment. World Blind Union estimated that $90 \%$ of blind or visually impaired people and print disabled come from developing and poor country while only $10 \%$ comes from developed country.4

In 2015, Statistics Central Bureau of Indonesia provides that, the number of blind people is $1,873,280$ people ${ }^{5}$. While the number of books that can be accessed by people with visually impair a little to be able to meet the needs of people with visual impairment of 98,678 per year 6 . This indicates that published books printed in Braille letter is very small in number. The very small number of works using Braille letter has caused concern from international world for the need of blind people. Copyright consists of art, literature and science. Copyright in the field of science aimed at people with visual impairment in the form of science books printed in braille. The field of science printed in Braille books are embodiments of copyright restrictions related to the needs of persons with visual impairment.7

The World Intellectual Property Organization (WIPO) in Geneva was certainly the right place and body to tackle this issue. However, despite the legitimate demand of blind and visually impaired persons, the negotiations on an international treaty were conducted slowly. ${ }^{8}$ WIPO as an international organization which organizes the protection of International Property Right made an international agreement that can facilitate blind people to get access for a work mentioned in Marrakesh Treaty (Marrakesh Treaty to Facilitate Access to Published Works for Persons who are Blind, Visually Impaired, or Otherwise Print Disabled)and enter into force September 2016. ${ }^{9}$ After being ratified by twenty countries. States parties must have a national legal rule on the exclusion of copyright to print books that are accessible to the blind people, such without the permission of the copyright holder such as the Braille book. Indonesia agreed and signed the Marrakesh treaty, but has not ratified the international agreement. However, copyright restrictions related to the needs of persons with blind people have existed since 1982 and are now regulated in Article 44 paragraph (2) of Law No. 28 of 2014 on copyright.

\section{Method}

The approach method that used in this research is normative juridical. Normative juridical research based on rules of law, in order to see the realities. The data used in this research is secondary data. Data collection was done by the literature research, are

4 The World Blind Union represents over 160 million blind and visually impaired person in 190 members countries, http://www.worldblindunion.org/English/about-wbu/Pages/default.aspx, Accessed on Feb 1, 2017

5 Statistics Indonesia, known in Indonesia as Badan Pusat Statistik (BPS), 2015, https://www.bps.go.id/Subjek/view/id/30\#subjekViewTab3|accordion-daftar-subjek1, Accessed on June 15, 2018

6 Balai Penerbitan Braille Indonesia (BPBI) Abiyoso. Available online at: https://bpbiabiyoso.kemsos.go.id/modules.php? name=ContentEpa $=$ showpageEpid $=16$

7 Catarina Sganga, (2015). Disability, Rights to culture and copyrights, which regulatory Option, international Review of Law Computer \& Technology (29) 2.

8 Köklü, K. (2014). The Marrakesh Treaty-time to end the book famine for visually impaired persons worldwide. Springer: IIC - International Review of Intellectual Property and Competition Law, Volume 45, Issue 7, pp 737-739.

9 Marrakesh Treaty to Facilitate Access to Published Works for Persons Who Are Blind, Visually Impaired, or Otherwise Print Disabled, June 28, 2013, Available online at: http://www.wipo.int/export/sites/www/treaties/en/ip/marrakesh/pdf/Marrakesh_Treaty.pdf, Accessed on March 19, 2018. 
studying the book, papers, literatures, journals, articles and legislation which is related to the object of research and related to the social situation that occurred in community.

\title{
3. Right of Access for Blind People to Literary Works as Human Right
}

The blind and visually impaired persons had a long history for finding ways to read and write. At the early of the 19th century, Laura Bridgman learned to communicate words using the sense of touch. He then managed to read by moving his fingers over the raised type. ${ }^{10}$ In 1829, Louis Braille invented a six-point dots system to help the blind read and write. It was not until the mid-19th century that the braille alphabet was widely used. Some 50 years later, Helen Keller, the first deafblind person to receive a Bachelor of Arts degree, used a braille system to read and then write 12 books and many articles. ${ }^{11}$

Since the mid-20th century, many technological developments including the invention of tape-recorders, personal computers, refurbished braille displays, and other adaptive technologies have increased access for the blind and visually impaired to reading material. ${ }^{12}$ The right to freedom to seek, receive and impart information, science and technology is the implementation of the right can be reduced, restricted or derogable rights..$^{13}$ The fulfillment of the right to freedom to seek, receive and impart information, science and technology for blind people in accordance with Article 9 of the UN Convention on the Rights of Persons with Disabilities (UNCRPD) and accessibility in obtaining information, science and technology both in form Documentation, braille books: ${ }^{14}$

\begin{abstract}
Works in the form of books printed in normal letters or not converted to Braille letters can only be accessed by normal people. If the books are converted from Latin letters into Braille letters, they can become accessible for blind people in fulfilling their right of freedom in getting information, knowledge, and technology. The conversion process from books for normal people only into books that can be accessed by blind people is considered interfering exclusive right held by the holders or the author of the books
\end{abstract}

The provision of documentation and books with braille related to copyright and there are adaptations of published works that may still be copyrights. The copyright owner has the right to benefit from the moral and material interests arising from a work of copyright which may be in the form of science, literature and art of a creed he creates under Article 27 (2) Universal Declaration of Human Rights-UDHR ${ }^{15}$. In Article 15 (1) (c) the International Covenant on Economic, Social and Cultural Rights -ICESCR, Article 19 Universal Declaration of Human Rights (UDHR) and Article 19 (2) International Covenant on Civil and Political Rights-ICCPR ${ }^{16}$. It is also contained in Article 21 of the

10 Freeberg, E. (2001). The Education of Laura Bridgman, Harvard University Press, Cambridge.

11 Freedman, R., and Kiesler, K. (1997). Out of Darkness: the Story of Louis Braille, Clarion Books, New York.

12 Lida Ayoubi, The Interface of Copyright and Human Right: Access of Works for The Visually Impairment, Master Degree Faculty of Law Lund University, Thesis Submitted to Victoria University of Wellington in fulfilment of the requirements for the degree of Doctor of Philosophy, 2015, Page 2 https://researcharchive.vuw.ac.nz/xmlui/bitstream/handle/10063/6116/thesis.pdf?

13 Rozali, A., and Syamsir. (2002). Perkembangan HAM dan Keberadaan Peradilan HAM di Indonesia,Jakarta, Ghalia Indonesia, p. 1.

14 Haryono, T.J.S., Kinasih, S.E., and Mas'udah, S. (2013). Akses dan Informasi bagi perempuan penyandang disabilitas dalam pelayanan kesehatan reproduksi dan seksualitas, Jurnal Masyarakat, Kebudayaan dan Politik, 26(2): 65-79.

15 Foster, S.E. (2009). Prolude and Compability Between human rights and Intellectual Property, Chicago Journal of International Law, Chi J I L. Vo. 9 No. 1, pp. 171-172

16 Darmawan, N.S. (2014). Relevansi hak kekayaan Intelektual dan Hak Azasi Manusia Generasi Kedua, Jurnal Medika Hukum, 14 (2): 521 
Convention on the Rights of Persons with Disabilities (CRPD). Human rights instruments justify the existence of restrictions of the exclusive rights of the authors as a balance to the exclusive rights of the authors as stipulated in Article 4 of the ICESCR. ${ }^{17}$ Besides, it is also stated in Article 21 Convention on the rights of Persons with Disabilities (CRPD). The arrangement is the basis of the right of access of blind people to the literary works 18

The regulation becomes the foundation of access right over works or creation. The right of access is human right owned by blind people. The implementation of access right over works or creation can be done by having regulation of copyright limitation regulated by a government of a country in order to limit the right owned by the creator or author of a work that has been transformed into media that can be accessed by blind people ${ }^{19}$. The implementation of access right over works or creation can be done by having regulation of copyright limitation regulated by a government of a country in order to limit the right owned by the creator or author of a work that has been transformed into media that can be accessed by blind people.

A government of a country can conduct limitation over right owned by the author or creator in order to achieve public interest. ${ }^{20}$ Copyright limitation in relation to the need of blind people is an action of copying works for blind people which is not considered against copyright. Blind people have the same rights as other normal people to get the benefits of science and technology, art and culture, ${ }^{21}$ in order to improve the quality of life. Government of a country has a very significant role in implementing access right owned by blind people over published works. Government of a country must perform the mandate to protect human right of blind people. A country in human right context is a duty bearer over all citizens. The obligation to respect is a country obligation to hold themselves not to discriminate and marginalize. This is the form of attitude and action for blind people to gain freedom to get, search and give information and knowledge through any media.

The State's obligation to protect is protection conducted by the country in order to help people with disabilities to avoid the potential of wasting, neglect or exploitation due to the lack of information and knowledge. Obligation to fulfill is The State's obligation to take legislative, administrative, juridical, and practical steps that needs to be done in order to fulfill the right of blind people over access to published works protected by copyright guaranteed by the constitution and also law.

17 Dagan, H., and Heller, M.A. (2001). The Liberal Commons, 110 YALE Law Journal, Page 549

18 Kushalnagar, R. (2014). Balancing Perceptual Disabled Consumers' Rights against Copyright Holders' Rights, Houston, Houston Law Center, page. 10

19 Paul Harpurdan Nicolas Suzor, Copyright Protection and disability Right: Turning the Page to a new International Paradigm, UNSWLawJl 29 (2013) 36(3) University on New South Wales Law Journal 745, 2013, p. 4

20 Nic Garnett, (2006), Auttomated Rights Management Systems and Copyright Limitation and Exception, WIPO, 27 April 2006, SCCR/14/5, p. 27

21 Gerard Quinn and Theresia Degener, (2002), Human Right and Disability, The current use and future potential of Nations human rights instruments in the context of disability, United Nation, New York 2002, https://www.ohchr.org/Documents/Publications/HRDisabilityen 


\section{Marrakesh Treaty to Facilitate Access to Literary Works for Blind People in Indonesia}

Regulation concerning the fulfillment of freedom to access owned by blind people over published works in the field of science protected by copyright has existed since Copyright Act No. 6 of 1982. The regulation explains that the copy of a work containing elements of science, art and literature using Braille letters meant for blind people is not considered against copyright (Article 14). The copy of the works is not against copy right if it does not involve commercial entities. Regulation about the fulfillment of freedom for the need of blind people in gaining knowledge is protected by copyright. This regulation indicates no significant changes regarding the fulfillment of freedom for the need of blind people in gaining knowledge protected by copyright. The government takes this issue seriously. This can be indicated by the statement about the fulfillment of freedom for the need of blind people in gaining knowledge protected by Copyright Act.

This arrangement is relevant to the regulation of copyright restriction in Article 44 paragraph (2) of the Copyright Act, $2014^{22}$ by excluding the rights of the author has been transformed or adapted into accessible media to the blind people. Besides the extension of infrastructure, this regulation also adds the range of users. The users are not only blind people, but also visually impaired people and limited print disabled people. There is also protection over moral right of the creator or author. The source of the information must be mention or cited in the works for blind people. ${ }^{23}$ This obligation in order to prevent from threat of futility, destruction or exploitation and others due to lack of information and knowledge for blind people.

A government of a country has a very important role in implementing freedom of published works for blind people. A government of a country has an obligation to protect human right of blind people. Indonesian government fulfils their obligation to meet the need of blind people to have the right to access published works in the field of science is by making legal regulation that guarantees the freedom. Regulation made by Indonesian government is regulation about copyright limitation in relation to facilitate access to published works for blind people. This regulation can limit the author's right over exclusive right he has for the work he created.

The regulation is the realization of obligation to respect the right of blind people to gain knowledge and information through published works made by the author or creator that has been transformed into printed media intended for blind people. Law can realize as much as happiness for people, in this case people are not only those who are normal, but also, those who are blind, visually impaired and other vision disorders. This is in accordance with utilitarianism theory.

The realization of welfare is by having real action that results in maximum equality from happiness over unhappiness. Happiness of normal people and blind people are considered and realized equally important ${ }^{24}$ Utilitarianism stresses on the result achieved from the distribution of resources that can be fair if the result achieved is "the greatest happiness for the greatest number". Greater happiness will be realized if government as policy maker makes rules that can facilitate blind people to be able to

22 Facilitation of access to a work for persons with visual impairment, persons with visual impairments or limitations in reading, and/or users of braille, audio books, or other means, is not considered a copyright violation if the source is mentioned or listed in full, except for commercial nature.

23 Rahayu. (2013). Hukum Hak Asasi Manusia (HAM). Semarang: Badan Penerbit Universitas Diponegoro, p 24-25.

24 Rachel, J. (2004). Filsafat Moral. Yogyakarta: Kanisius, p. 187. 
access published works in the field of science in order to get the same information and knowledge as normal people. Further regulation regarding facilitating access to published works for blind people will be the foundation for blind people to be able to get more information and knowledge without being worried that the activity is against copyright.

The regulation on facilitation of access to copyright in the field of science in Indonesia is already to get knowledge and information to people blind ant the people with visual impaired, already exist but not yet maximal. The policy has not yet clearly set out the mechanisms, governance and institutions responsible for the fulfillment of access facilitation for the disability of the work of the scientific know-how. Government as a duty bearer to respect the right of blind people can formulate legal protection for blind people to facilitate access to published works based on Marrakesh Treaty. There are many factors that should be taken into account especially in the process of the formulation. The provisions of the accessable of disability to literary work are regulated in Marrakesh Treaty to Facilitate Access to Published Works of Persons who are Blind, Visually Impaired, or Otherwise Print Disabled 2013. Marrakesh Treaty 2013.

Marrakesh Treaty (Marrakesh Treaty to Facilitate Access to Published Works for Persons who are Blind, Visually Impaired, or Otherwise Print Disabled) is the most recent treaty in the field of copyright issued by World Intellectual Property Organization (WIPO). This treaty has human and social development dimensions aimed at giving mandate to form limitations and exceptions of copyright for the sake of blind people. ${ }^{25}$ Marrakesh treaty can facilitate blind people to be able to use and read books using Braille letters more than before.

Marrakesh Treaty conveys the most important elements regarding the regulation of facilitation of access to published works for blind people thus this can improve the implementation of the access right held by blind people. This should be regulated in the next Government regulation:

a) Restrictions on Beneficiary person that is for The People Blind, Visually Impaired, or Otherwise Print Disabled. The regulation about definition of published works that can be categorized as a type of published works that limitations and exceptions from copyright can be applied is very important. This definition can regulate more specifically the types of published works that can apply limitations and exceptions of copyright; 26

b) Restrictions on the type of literary work accessed are all literary, art works arranged in the Bern Convention but exception for audio-visual and film copyright. The regulation about definition of published works that can be categorized as a type of published works that limitations and exceptions from copyright can be applied is very important. This definition can regulate more specifically the types of published works that can apply limitations and exceptions of copyright; 27

c) Restriction of accessible format copying, that is, accessible to persons with visually impaired by enlarging letters and specifically accessible for blind people by copying. Strict and clear regulation about the copy format that can be accessed by blind

25 Kaminski, M.E., Yanisky-Ravid, S. (2014). Marakest Treaty for Vissually Impairment Persons, Why was the Treaty Preferrable To Soft Law, University of Pittsburgt Law Review, Vol. 75. DOI 10.5195/lawreview.2014. Page 272 http:/ / lawreview.law.pitt.edu

26 Grifitts, Y. (2009). The 'Three-Step Test' in European Copyright Law - Problems and Solutions, Queen Mary, University of London, School of Law Legal Studies Research Paper Series No. 31/2009. https://papers.ssrn.com/sol3/papers.cfm?abstract_id=1476968\#\#

27 WIPO. (2016). Marakest Treaty- Helping To End Global Book Famine, Overview World Intellectual Property Organization, Page 4.www.wipo.int/edocs/.../wipo_pub_marrakesh_overview.pdf 
people becomes important because the copy format is specifically intended for blind people and other visually impaired people; 28

d) The institution requirement to be fulfilled, that is an entity authorized by the government, either a government agency or a non-profit institution, a special institution dealing with disability. An entity that has authority to regulate facilitating access to published works for blind people is defined as an entity that has authority in conducting reproducing, distribution of a published works that commonly become printed media that can be accessed by blind people;

e) Implementation of fair use principles. Regulation of limitations and exceptions for blind people is very important. This regulation states that approval or permission from the author or copyright holder is not required for using their works and converting them into printed media that can be accessed by blind people and people with other visual disabilities;

f) Restrictions on cross border access. This regulation allows the exchange of copies of format accessible to blind people. This can be done by the authorized entities with other countries that are members of Marrakesh Treaty.

For this reason, Indonesia signed to agree but has not ratified on the Marrakesh treaty. The Indonesian government just adapted the Marrakesh treaty into one of the articles (Article 44 paragraph 2) of Law No. 28 of 2014 on Copyright. will be further regulated under a Government Regulation. The formulation of future Government Regulations is expected to be better able to fulfill the right of facilitation of access to copyrights for the visually impaired. The Marrakesh Treaty may be a reference in the formulation of the rule. Certainly, the provisions of the Marrakesh agreement could be flexibly interpreted as a valuable mechanism for introducing flexibility into closed copyright systems to suit the needs of blind people and people with other visual disabilities in Indonesia.

Indonesia as agreed, signed and has not yet ratified or has not a consent to be bound against Marrakesh is only morally binding to the treaty. However, the provision of the right of accessibility to the literary works for blind people is a part of deregoble of human rights, so that this provision is the imperative norm or pre-emptory norm which must be fulfilled by each country. Thus, Indonesia adopted the provision of facilitate access to literary works for blind people through the provisions of article 44 paragraph (4) of Copyright Act No. 28 of 2016.

Regulation about the fulfillment of freedom to access owned by blind people over published works in the field of science protected by copyright has existed since Law No. 6 Year 1982 about Copyright Article 14 (d). The regulation explains that the copy of a work containing elements of science, art and literature using Braille letters meant for blind people is not considered against copyright. The copy of the works is not against copy right if it does not involve commercial entities. The reproduction of the works are not commercial nature and does not harm the fair use of its author. ${ }^{29}$ The arrangements of wider accessable are regulated in the Copyright Act 2014, that is a legislation to facilitate access to works not only books using braille but also audio books, printing of books with large letters. This regulation is referred to as one form of copyright restriction. Copyright restrictions related to the needs of blind people to literary works are not included in the act of copyright infringement.

28 Lavizzari, C.S. (2016). IPA Guide to the Marrakesh TreatA guide for publishers and their trade associations in membership with the IPA, Lenz Caemmerer Attorneys \& Notaries Basel Switzerland, Page 14.

29 Masdurohatun, A., \& Mansyur, M.A. (2015). Identifikasi Fair Use/ Fair Dealing Hak Cipta Atas Buku Dalam Pengambangan IPTEK Pada Pendidikan Tinggi di Jawa Tengah, Fakultas Hukum Universitas Islam Sultan Agung, p. 17 
The inclusion of the regulation on the fulfillment of freedom of accessable to blind people in obtaining science protected by copyright in the Copyright Act as reflects the appearance really of the Indonesian Government in regulating the freedom of blind people to still gain knowledge and information to improve the quality of self. This is many of countries the problems posed by copyright protection as access barriers have received legislative attention in the form of attempts to remove them. Those attempts have not always given rise to perfect solutions. However, this arrangement has not been sufficient to meet the accessibility of the works by the blind people because until now there has not been a National Disability Commission (as mandated in article 131 of Law No. 8 of 2016 on Disability) which should be the authorized institution and the responsibility to provide facilitation accessibility includes use, retrieval, duplication, change of format, announcement, distribution, and/or communication of works. Above all, the Government Regulation as mandated in the Copyright Act to further regulate accessible facilitation mechanisms until now has not been made by the Government.

\section{Conclusion}

The arrangement of facilitate access to literary works for blind people in Indonesia has existed since Copyright Act No. 6 of 1982 to Copyright Act No. 28 of 2014 and Disability Act No. 8 of 2016, but in practice, the regulation is still inadequate for the protection of blind people to fulfill the right of access to the literary works to obtain in common with other normal persons. The Government has an important role to realize the right of access to the wider blind people by forming government regulations in accordance with the mandate of Article 44 paragraph (4) of the Copyright Act 2014 and the Government shall immediately establish a National Commission on Disability authorized and responsible to meet the facilitation of access for blind people, persons with visual impairment and the limitation of reading by referring to Marrakesh Treaty or by looking at other regulatory practices of other country. This arrangement is expected to have an effect of increasing the index of the number of printed materials accessible to blind people with in Indonesia.

\section{References}

Dagan, H., and Heller, M.A. (2001). The Liberal Commons, 110 YALE Law Journal, p. 549

Darmawan, N.S. (2014). Relevansi hak kekayaan Intelektual dan Hak Azasi Manusia Generasi Kedua, Jurnal Medika Hukum, 14 (2): 521

Foster, S.E. (2009). Prolude and Compability Between human rights and Intellectual Property, Chicago Journal of International Law, Chi J I L. Vo. 9 No. 1, pp. 171-172

Freeberg, E. (2001). The Education of Laura Bridgman, Harvard University Press, Cambridge.

Freedman, R., and Kiesler, K. (1997). Out of Darkness: the Story of Louis Braille, Clarion Books, New York.

Gerard Quinn and Theresia Degener, (2002), Human Right and Disability, The current use and future potential of Nations human rights instruments in the context of disability, United Nation, New York 2002, https://www.ohchr.org/Documents/Publications/ HRDisabilityen 
Grifitts, Y. (2009). The 'Three-Step Test' in European Copyright Law - Problems and Solutions, Queen Mary, University of London, School of Law Legal Studies Research Paper Series No. 31/2009. https://papers.ssrn.com/sol3/papers.cfm?abstract_id=1476968\#\#

Haryono, T.J.S., Kinasih, S.E., and Mas'udah, S. (2013). Akses dan Informasi bagi perempuan penyandang disabilitas dalam pelayanan kesehatan reproduksi dan seksualitas, Jurnal Masyarakat, Kebudayaan dan Politik, 26(2): 65-79.

Kaminski, M.E., Yanisky-Ravid, S. (2014). Marakest Treaty for Vissually Impairment Persons, Why was the Treaty Preferrable To Soft Law, University of Pittsburgt Law Review, Vol. 75. 272 http://lawreview.law.pitt.edu

Kastowo. (2015). Rekonstruksi Fungsi Sosial Hak Cipta sebagai Hak Milik, Jurnal Yusticia At Pax, 31 (2): 1-15

Köklü, K. (2014). The Marrakesh Treaty-time to end the book famine for visually impaired persons worldwide. Springer: IIC - International Review of Intellectual Property and Competition Law, Volume 45, Issue 7, pp 737-739.

Kushalnagar, R. (2014). Balancing Perceptual Disabled Consumers' Rights against Copyright Holders' Rights, Houston, Houston Law Center.

Lavizzari, C.S. (2016). IPA Guide to the Marrakesh TreatA guide for publishers and their trade associations in membership with the IPA, Lenz Caemmerer Attorneys \& Notaries Basel Switzerland.

Lida Ayoubi, The Interface of Copyright and Human Right: Access of Works for The Visually Impairment, Master Degree Faculty of Law Lund University, Thesis Submitted to Victoria University of Wellington in fulfilment of the requirements for the degree of Doctor of Philosophy, 2015, Page 2 https://researcharchive.vuw.ac.nz/xmlui/ bitstream/handle/10063/6116/thesis.pdf?

Marrakesh Treaty to Facilitate Access to Published Works for Persons Who Are Blind, Visually Impaired, or Otherwise Print Disabled, June 28, 2013, Available online at: http://www.wipo.int/export/sites/www/treaties/en/ip/marrakesh/pdf/Marrakesh_Treaty.p df, Accessed on March 19, 2018.

Masdurohatun, A., \& Mansyur, M.A. (2015). Identifikasi Fair Use/ Fair Dealing Hak Cipta Atas Buku Dalam Pengambangan IPTEK Pada Pendidikan Tinggi di Jawa Tengah. Semarang: Fakultas Hukum Universitas Islam Sultan Agung.

Nic Garnett, (2006), Auttomated Rights Management Systems and Copyright Limitation and Exception, WIPO, 27 April 2006, SCCR/14/5.

Paul Harpurdan Nicolas Suzor, Copyright Protection and disability Right: Turning the Page to a new International Paradigm, UNSWLawJl 29 (2013) 36(3) University on New South Wales Law Journal 745, 2013, p. 4

Pooja Shree, (2015). Disability Exeptions in Copyright, Selvam \& Selvam, https://selvams.com/blog/disability-exceptions-copyright

Rachel, J. (2004). Filsafat Moral. Yogyakarta: Kanisius.

Rahayu. (2013). Hukum Hak Asasi Manusia (HAM). Semarang: Badan Penerbit Universitas Diponegoro.

Rozali, A., and Syamsir. (2002). Perkembangan HAM dan Keberadaan Peradilan HAM di Indonesia,Jakarta, Ghalia Indonesia, p. 1.

Statistics Indonesia (Badan Pusat Statistik/BPS), 2015, https://www.bps.go.id/Subjek/view/ id/30\#subjekViewTab3 |accordion-daftar-subjek1, Accessed on June 15, 2018 
Sganga, C. (2015). Disability, Rights to culture and copyrights, which regulatory Option, international Review of Law Computer \& Technology (29) 2.

WIPO. (2016). The Marrakesh Treaty- Helping to End Global Book Famine, Overview World Intellectual Property Organization, p. 4. https://www.wipo.int/edocs/ pubdocs/en/wipo_pub_marrakesh_overview.pdf

World Health Organization, 2017 Fact Sheet N 282, Available online at: http://www.who.int/en/news-room/fact-sheets/detail/blindness-and-visual-impairment, Accessed on Feb 14, 2018. 